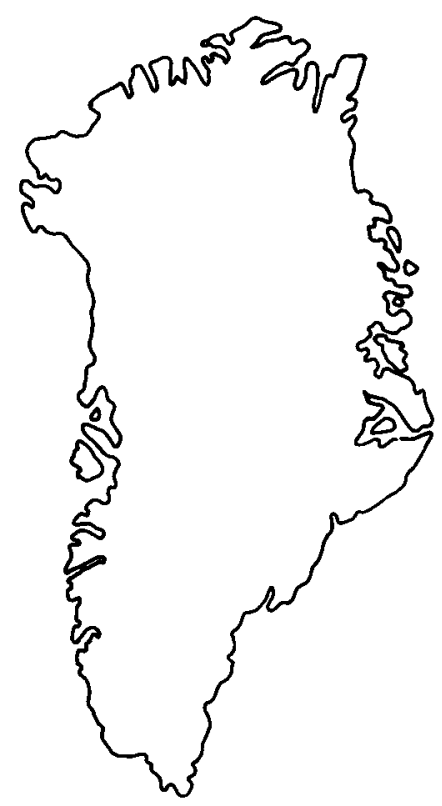

\title{
The high-grade gneisses in the south-west of Dove Bugt: an old gneiss complex in a deep part of the Caledonides of North- East Greenland
}

\author{
B. Chadwick and C. R. L. Friend
}

\begin{abstract}
The complex range of orthogneisses has been subdivided on the basis of field characteristics into an old polyphase group, grey phlebitic gneisses, younger varieties of pink granitic gneisses that occur principally as extensive sheets, mixed orthogneisses with schlieric facies and undifferentiated gneisses with dioritic facies. Mafic sheets, now amphibolites, were emplaced at various stages in the evolution of the gneisses. Enclaves and sheets of supracrustal rocks include paragneisses, graphitic schists, marble, amphibolite and stratiform gabbroic complexes with anorthosite.

Nappes with curvilinear hinge lines and belts of mylonite developed in high amphibolite conditions after emplacement of the sheets of pink granitic rocks (now variably deformed gneisses) into the old orthogneisses and supracrustal rocks. Principal displacements in the mylonites were shallow and $\mathrm{N}$-directed. The nappes and mylonites were deformed by upright-inclined folds with north-westerly vergence. The nappes, mylonites and north-westerly verging folds are presumed to be Caledonian. $\mathrm{N}$ - and S-directed extensions indicated by small-scale ductile structures younger than the regional folding suggest that longitudinal collapse predominated in this part of the Caledonian belt in the south-west of Dove Bugt.
\end{abstract}

B. C., Earth Resources Centre, University of Exeter, Exeter EX4 4QE, U.K.

C. R. L. F., Department of Geology, Oxford Polytechnic, Oxford OX3 OPB, U.K.

The high-grade gneisses of Dove Bugt were mapped on a reconnaissance basis in 1989 (Chadwick et al., 1990) as part of the North-East Greenland project (Henriksen, 1989). The reconnaissance revealed that the gneisses had undergone at least four phases of folding and several periods of migmatisation. Selected areas in the south-west of Dove Bugt were mapped at a scale of 1:20000 in 1990. They included the north-western part of Rechnitzer Land, most of Lindhard $\varnothing$ and part of the south-east of Daniel Bruun Land (Fig. 1). Our principal objectives were to classify the gneisses on the basis of field criteria and establish their tectonic setting with a view to assessing the role of Caledonian deformation and metamorphism within the old high-grade gneiss terrain in this part of the North-East Greenland Caledonides.

Proterozoic and Archaean gneiss-forming events are indicated by preliminary isotopic data from the Dove Bugt region (Steiger et al., 1976; F. Kalsbeek, personal communication, 1990), but no age data are available from the gneisses in the south-west of Dove Bugt. Important ambiguities exist with regard to the age of the supracrustal rocks which form persistent structural markers within the orthogneisses. The abundance of marble suggests that the supracrustal suites have more in common with Proterozoic than Archaean associations, but their juxtaposition with stratiform gabbroanorthosites comparable with those in southern West Greenland suggests an Archaean age. Friderichsen et al. (1990) have demonstrated that Caledonian deformation at a relatively high crustal level affected the gneisses and younger sedimentary sequences in the western border of the North-East Greenland Caledonides exposed in Dronning Louise Land. Dove Bugt is separated from this borderland by the ice of Storstrømmen and consequently no direct links can be made with known Caledonian structures.

The distribution of the gneisses is described in terms of three areas that are separated by major faults, one of which is concealed by the waters of Borgfjorden (Fig. 1). The southern area includes the north-western part of Rechnitzer Land and a major peninsula between Rechnitzer Land and Lindhard $\varnothing$. We propose that the peninsula be called 'Janet Watson Halvø' in recognition of the work of the late Professor J. V. Watson in the old gneiss complexes in the Caledonian belt of Scotland. 

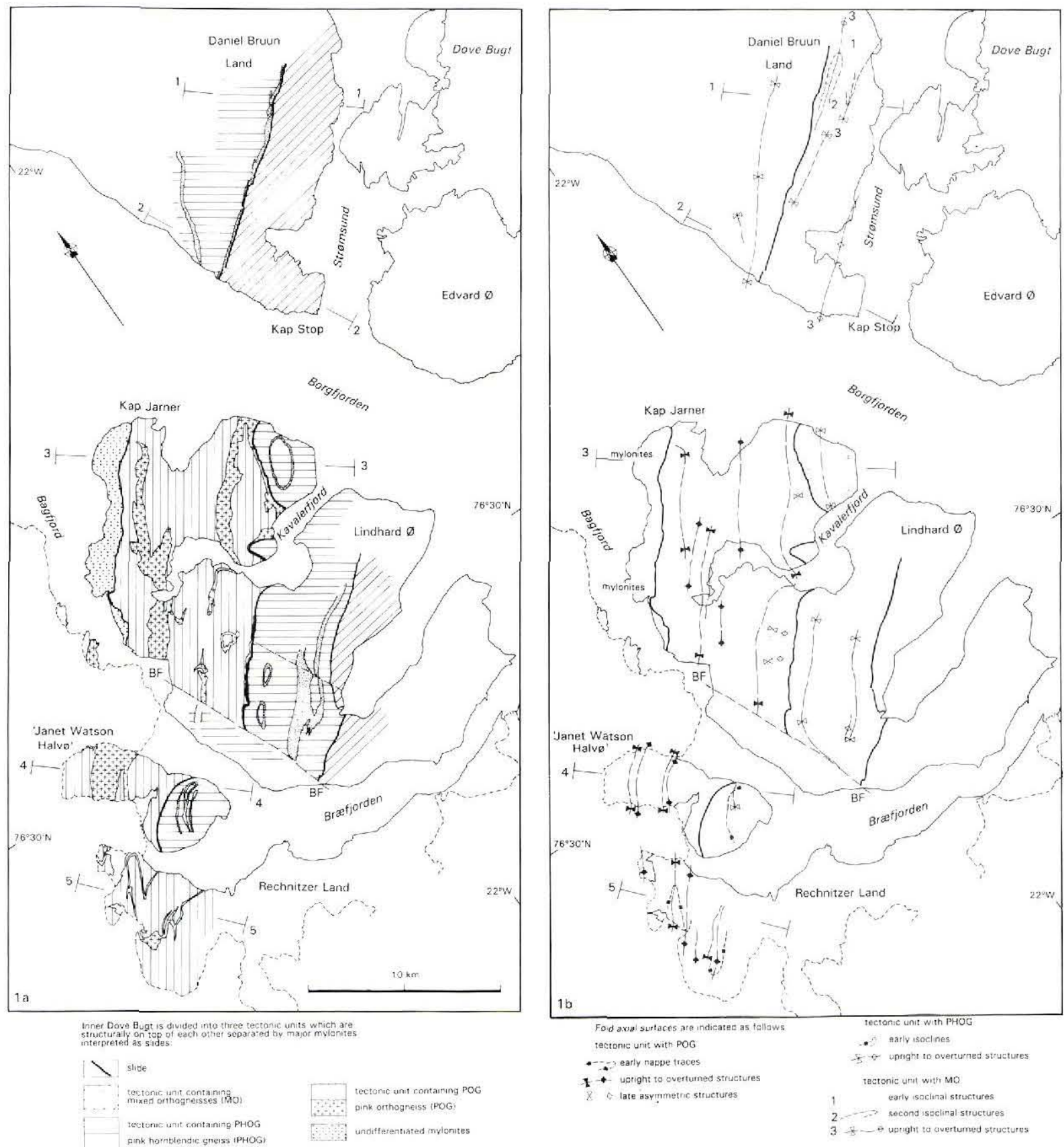

Fig. 1. Sketch maps of the Dove Bugt region across northern Rechnitzer Land, Lindhard $\varnothing$ and Daniel Bruun Land. (a) Sketch showing major units of orthogneiss and the division of the region into three different tectonic units. Each unit is separated by mylonite zones of variable thickness and indicated as slides. Cross section lines for Fig, 2 are indicated and numbered 1-5. (b) Sketch showing the disposition of the axial traces of the major fold found in each tectonic unit.

The peninsula is separated from the central area by the Bagfjord Fault, part of which is exposed in the southwest of Lindhard $\varnothing$. It is steep, with a presumed dextral displacement. The central area comprises all of Lindhard $\varnothing$ except for the small part south of the Bagfjord
Fault. The central area is separated from the northern area by the waters of Borgfjord. The northern area comprises the south-eastern part of Daniel Bruun Land. A major sinistral fault is presumed to occur beneath Borgfjord. The fault is suggested by the relative dis- 
placement of the major belt of mylonites in the northwest of Lindhard $\varnothing$ and the mylonites in a group of islands south-west of Daniel Bruun Land (Bræøerne; see Chadwick et al., 1990). Three major tectonic units are suggested by the distribution of asymmetric folds and the principal varieties of orthogneiss. Parts of each of the units occur in each area (Fig. 1). The units are separated from each other by tectonic slides whose position has been inferred from thin zones of mylonitised marble or gneiss.

\section{Quartzo-feldspathic orthogneisses}

Simple field characteristics were used to erect a detailed classification of the gneisses, although application of the scheme is rendered difficult in some instances because of the effects of heterogeneous deformation and variations in weathering colours. The relative ages of many of the principal gneiss types are uncertain because of the lack of discordant contacts and the restriction of some types to different parts of the complex structure. The first type (old orthogneisses) is regarded as the oldest on the grounds that it is intruded by all of the other types.

\section{Old orthogneisses}

The old orthogneisses are heterogeneous, mainly grey, biotitic polyphase gneisses with abundant white pegmatite banding. Enclaves of variable amphibolitic composition, including locally abundant leuco-gabbro with coarse plagioclase, are common. Many enclaves display variable degrees of disaggregation and incorporation into their host gneisses. The old orthogneisses are intersheeted with older supracrustal rocks. It is conceivable that some of the sheets of supracrustal rocks may be younger and were juxtaposed tectonically with the old orthogneisses. The old orthogneisses are so intimately mixed with supracrustal rocks that they could not be separated and were mapped as mixed gneisses.

\section{Grey homogeneous gneisses}

These are medium- to coarse-grained, biotite-hornblende gneisses with a flecked texture formed by feldspar-quartz aggregates a little coarser than the matrix. The gneisses have a conspicuous white pegmatite layering and in many instances a phlebitic structure of irregular, but evenly distributed, white quartzo-feldspathic segregations. Hornblende may occur in the segregations, but it is not characteristic. This variety of gneiss has been recognised only on Lindhard $\emptyset$. It forms sheets up to $300 \mathrm{~m}$ thick which include variably deformed basic dykes in the form of pods up to $150 \mathrm{~m}$ long. Discordances between the dykes and their host gneisses are preserved in a few outcrops.

\section{Pink hornblendic gneiss}

These greyish-pink, homogeneous, medium- to coarse-grained, biotite-hornblende gneisses are characterised by a phlebitic structure of coarse, pink quartzofeldspathic aggregates which include hornblende as a universal component, commonly as poikiloblasts up to 2 $\mathrm{cm}$ in length. The presence of hornblende and the pink colour of the aggregates distinguish these gneisses from all other types. The dark selvedge surrounding many of the aggregates suggests that they formed as in situ partial melts or metamorphic segregations. The pink hornblendic gneisses occur as sheets with a maximum estimated thickness of $500 \mathrm{~m}$ on 'Janet Watson Halvø', Lindhard $\varnothing$ and Daniel Bruun Land.

\section{Pink augen gneisses}

These gneisses are biotitic, typically with a pink weathering cast, but the fresh rock is grey. They have been recognised only in Daniel Bruun Land. In areas of low strain the gneisses are characterised by crowded augen of pink feldspar, but in areas of high strain the augen are not distinctive because the feldspar appears largely as an integral part of the coarse groundmass. The gneisses may include at least three generations of pegmatite. Early veins are a few centimetres thick with dark selvedges suggesting in situ partial melting or metamorphic segregation. These veins are commonly folded by small isoclines which have been refolded by at least two later phases of folding. Pegmatites a few centimetres thick are commonly broadly coplanar with the axial surfaces of one of these later phases. Younger, diffusely banded pegmatites which are discordant to the coplanar veins are tentatively correlated with the youngest principal phase of regional folding. The pink augen gneisses include a few persistent sheets of amphibolite with low-angle discordant contacts.

\section{Mixed orthogneisses}

This suite comprises two facies, namely, an older grey, homogeneous, medium- to coarse-grained, flecked biotite gneiss with variable amounts of white pegmatite layering, and a younger pink inhomogeneous granitic gneiss which commonly has a schlieric aspect. The schlieric characteristic results from an intimate association of greyish gneiss and pink, coarser grained, locally pegmatitic phases. Whilst much of the schlieric 
structure can be regarded as the result of intermingling of broadly comagmatic phases, the disaggregation of enclaves of gneiss and amphibolite suggests that significant additions have been made from older material. The pink facies is cut by sheets of pre- or syntectonic, pink pegmatite and aplite. Layers of disseminated aggregates of coarse magnetite are relatively common in the pink facies. Comagmatic or syntectonic mafic dykes with highly irregular and discontinuous outcrop are found locally in the pink facies. The older grey facies is cut by amphibolite dykes ranging from 0.5 to $50 \mathrm{~m}$ thick and up to $2 \mathrm{~km}$ long. These dykes are cut by the pink facies. The mixed orthogneisses have been recognised in much of the area mapped in Daniel Bruun Land and in a limited area in the south-east of Lindhard $\emptyset$.

\section{Pink porphyritic gneiss}

This is a homogeneous granitic gneiss with conspicuous porphyritic pink to red microcline, though the porphyritic texture is not universal. Fluorite occurs locally as an accessory mineral. The gneiss is foliated but it lacks banding and pegmatite layers. It is found as broadly conformable sheets up to $c .100 \mathrm{~m}$ thick within a major complex of supracrustal rocks in the north-western part of Rechnitzer Land. The gneiss also occurs as persistent sheets in mixed gneisses and supracrustal sheets in the western part of 'Janet Watson Halvø' and Lindhard $\emptyset$ (Fig. 1).

\section{Undifferentiated orthogneisses}

Various grey gneisses that do not fit into the foregoing classification occur within the south-east of each of the areas mapped in Lindhard $\varnothing$ and Daniel Bruun Land. These gneisses include polyphase, augen-bearing, pegmatite-banded and phlebitic types with aspects in common with those of the grey homogeneous gneisses on Lindhard $\varnothing$, but no firm correlation can be made. They also include mafic dioritic types. Some of the undifferentiated gneisses are barren of enclaves, but pods and sheets of amphibolite are common in others.

\section{Carbonate-rich grey orthogneiss}

A zone of nodular carbonate-rich grey orthogneiss a few metres thick and with a strike length of at least $50 \mathrm{~m}$ occurs in the western part of Lindhard $\emptyset$. The zone appears to be broadly parallel to foliation in the host gneisses. These altered gneisses are characterised by abundant calcite with local fluorite. The significance of the carbonate enrichment in terms of the regional geology is unclear. The enrichment may be related to car- bonate seams in the Bagfjord Fault zone or carbonatequartz breccias in mylonitised orthogneisses on the islands south-west of Daniel Bruun Land which suggest localised, late or post-tectonic, high fluid pressures. The age of the veins and breccias is unknown.

\section{Correlation of the pink granitic gneisses with others in the south-west of Dove Bugt}

Other major sheets of pink granitic orthogneisses occur on islands east of Daniel Bruun Land, in the north of Daniel Bruun Land and north of Hellefjord and Mørkefjord (Chadwick et al., 1990). These sheets have much in common with the pink orthogneisses and the pink augen gneisses, although their degrees of migmatisation and deformation are variable. All of the varieties of pink granitic orthogneiss, including the pink hornblendic type, were emplaced before the main nappes were generated. On the grounds of their composition and place in the regional chronology, we suggest that the sheets of pink granitic orthogneisses in the west and south-west of Dove Bugt were broadly contemporaneous.

\section{Supracrustal rocks}

Details of the main supracrustal lithologies were summarised by Chadwick et al. (1990). Enclaves of supracrustal rocks within the old orthogneisses indicate their relative age, but isotopic data are necessary to determine whether they are Archaean or Proterozoic. Musgravite, a Be-Mg-Al oxide, has been identified in a marble collected in 1989 from an island east of Strømsund. This is the first recorded occurrence of this mineral in Greenland. Its restriction to a marble immediately below a sheet of foliated red granite suggests that the beryllium was introduced from the granitic intrusion. Many of the sheets of marble include disseminated graphite, whilst some schists contain up to $15 \%$ graphite. Some marbles contain abundant chondrodite and others include spinel. The paragneisses contain cordierite and sillimanite. The latter is coaxial with the regional transport direction in a mylonitised paragneiss on Lindhard $\emptyset$, a relationship indicating the metamorphic conditions of mylonitisation.

\section{Gabbroic rocks}

Relict phase layering is preserved locally in the major sheet of stratiform gabbro found in the Kap Stop peninsula in 1989 (Chadwick et al., 1990), but it has no stratigraphic significance because of the intense tectonic disruption. There is a broadly systematic distribution of 
gabbro and mela-gabbro on the south-eastern flank of the sheet, leuco-gabbro and subordinate anorthosite s.s. in the centre and gabbro and abundant sheets of undifferentiated and old grey orthogneiss on the north-west.
A major belt of gabbro is separated from the north-west of the main sheet in the area of Kap Stop by grey orthogneisses. Further north-west old orthogneisses and mixed orthogneisses are intersheeted with numerous

1
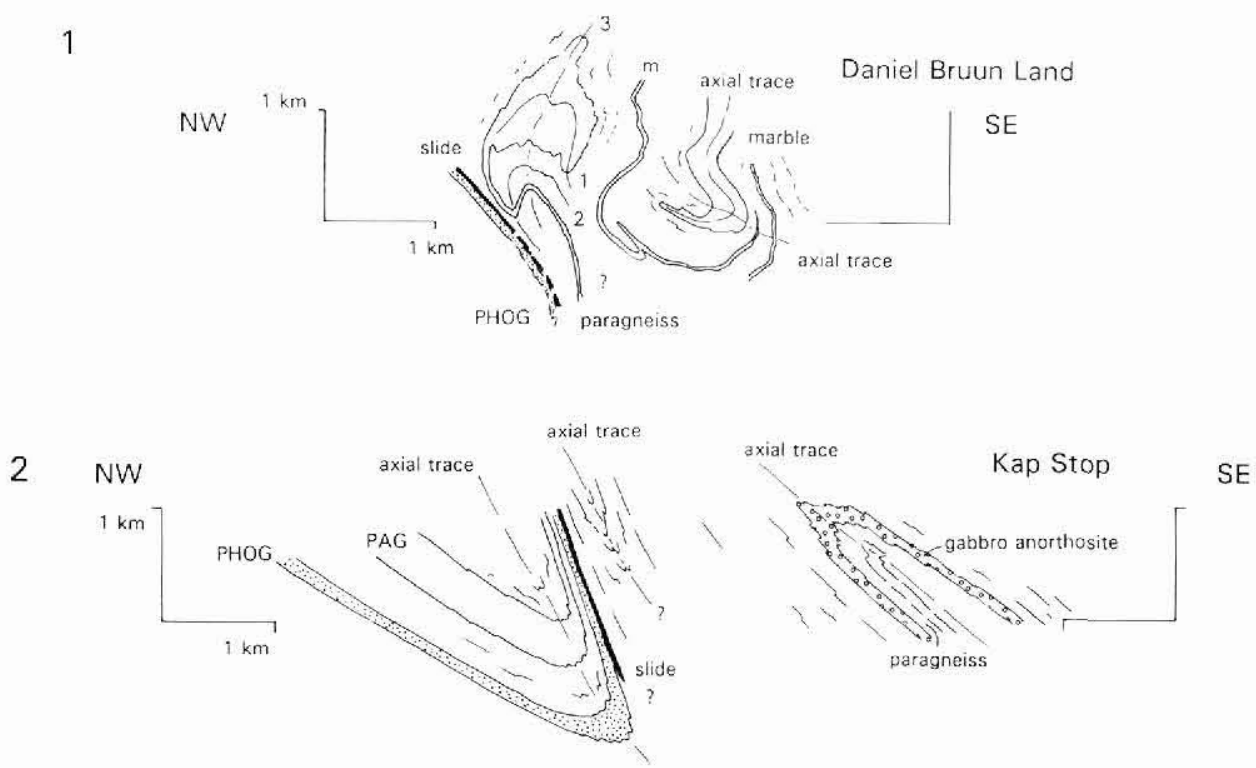

$3 W \quad$ NW Lindhard $\varnothing$

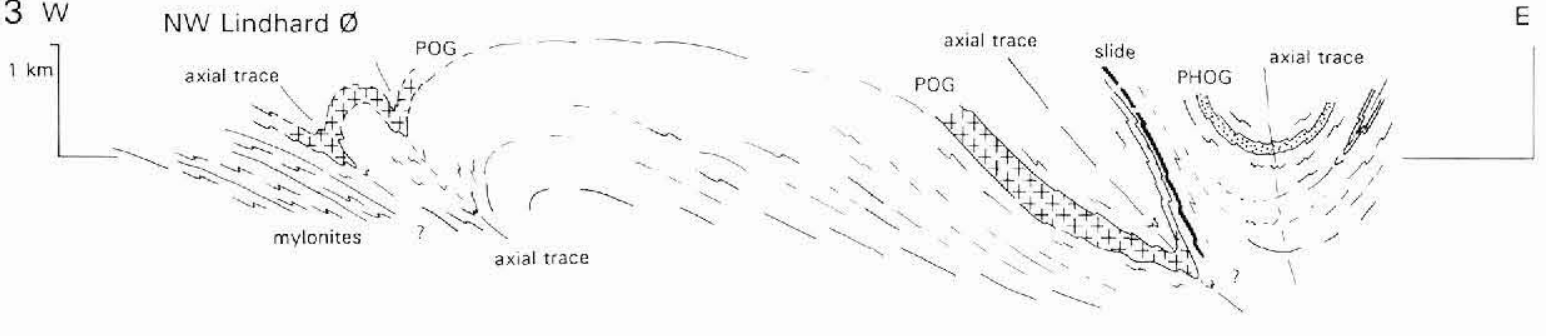

4 NW Janet Watson Halvø

SE

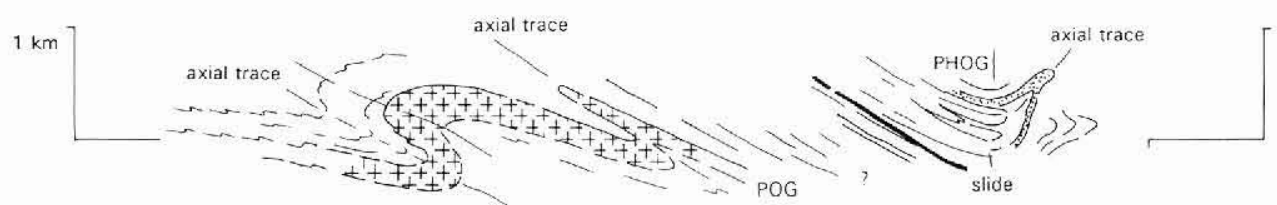

5

NW

NW Rechnitzer Land

SE

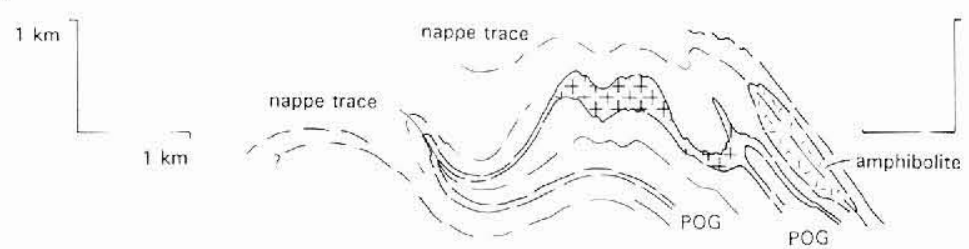

Fig. 2. Cross sections to illustrate the regional structure. Sections are ordered from north to south; see Fig. 1 for section lines. 
layers of gabbro which include leucocratic and mafic types. The relatively thin sheet of gabbro on the southeastern limb of the large antiform in the Kap Stop peninsula is the equivalent of the main sheet on the western limb. One other major body of gabbro and mela-gabbro with minor leuco-gabbro was discovered on the flank of a persistent sheet of migmatised paragneisses and amphibolites on the slopes north-west of Strømsund. It is variably disrupted by mixed orthogneisses. Enclaves of leuco-gabbro with coarse plagioclase occur widely in the orthogneisses of Lindhard $\varnothing$ (Chadwick et al., 1990, fig. 3).

\section{Structure}

The structural complexity recognised by Chadwick $e t$ al. (1990) has been confirmed, but new data in the form of the distribution of particular categories of orthogneisses show that the structure may be considered in terms of three tectonic units (Fig. 1) that are separated by tectonic slides marked by thin zones of mylonite.

A prominent linear fabric is found in most outcrops within each of the tectonic units. It plunges gently SW in the north-western part of Rechnitzer Land and Lindhard $\varnothing$, but gently NE in Daniel Bruun Land. Hinge lines of boat-shaped folds are curved about the southwesterly plunging linear fabric in Daniel Bruun Land. The $L$ fabric is formed by the preferred orientation of long axes of prismatic minerals, quartz aggregates and pegmatitic segregations. Locally intense development of the fabric gives rise to $L$ tectonites. The $L$ fabric is coaxial with small-scale folds and it is parallel to the shallow NE-directed displacement indicated by shear criteria such as feldspar $\sigma$-structures in many of the mylonites on Lindhard $\emptyset$.

Coarse, non-penetrative $S$ fabrics formed by minerals and aggregates are broadly concordant with layering in the gneisses and supracrustal rocks. Younger, discordant $S$ fabrics are broadly coplanar with folds in some outcrops. These $S$ fabrics are defined by non-penetrative mineral preferred orientations and veins or diffuse aggregates of pegmatite. $S$ fabrics in mylonites are commonly penetrative and are generally combined with the linear fabric to form $L S$ tectonites. Oblate strains associated with these $L S$ tectonites are indicated by chocolate tablet boudinage of thin sheets of amphibolite in some of the mylonites on Lindhard $\emptyset$.

\section{North-west Rechnitzer Land and 'Janet Watson Halv $\emptyset^{\prime}$}

Sheets of pink porphyritic orthogneiss (Figs 1, 2.5) form important structural markers and they provide a link with the central area north of the Bagfjord Fault on Lindhard $\emptyset$. A persistent sheet in the north-western part of Rechnitzer Land outlines a major interference pattern formed by the superimposition of upright and inclined folds on regional isoclines or fold nappes. The younger folds plunge gently SW coaxial with the regional linear fabric. They verge north-west (Fig. 2.5) and they may be parasitic on a much larger regional fold. The form of the interference pattern suggests that the nappes are broadly coaxial with the younger folds, but the closed eye-like structure indicated by the outcrop of undifferentiated, creamy pink orthogneiss in the core of one of the nappes suggests that the early folds are sheath structures with extreme curvature of their hinge lines. A large antiformal isocline with a core of amphibolite in the south-east of the interference pattern is coaxial with the linear fabric in part, but its gross geometry suggests that its hinge line is also curved. It is not clear whether the isocline is parasitic on the large refolded nappe cored by the orthogneisses or older. The geometrical relationships within the interference pattern suggest that nappes with sheath forms, some of which are curvilinear about the regional linear fabric, are an important part of the regional structure. Deformation of gneissic banding and migmatitic structures in the supracrustal rocks indicates a complex tectonic and metamorphic history prior to nappe development in the north-western part of Rechnitzer land. The lack of migmatitic characteristics in the sheets of pink orthogneiss suggests however that injection of granitic sills took place prior to the isoclinal folding but after the complex history recorded in the supracrustal rocks and old orthogneisses. The presence of pink sheets resembling the younger facies of the mixed orthogneisses in the old orthogneisses in the highest part of the structure in the north-western part of Rechnitzer Land suggests that it correlates with the tectonic unit in the south-east of Lindhard $\emptyset$.

A major sheet of pink porphyritic orthogneiss defines a large asymmetric antiform and a smaller synformantiform system in the north-west of 'Janet Watson Halvø' (Fig. 2.4). The thickness of the sheet is unknown because its base is not exposed. The folds plunge gently south-west, they have axial surfaces dipping south-east, they verge north-west and they deform earlier isoclines. On these grounds the folds may be correlated with the younger upright-inclined folds in the north-western part of Rechnitzer Land (Fig. 1b).

The south-eastern part of 'Janet Watson Halvø' is characterised by sheets of pink hornblendic orthogneiss and other pink orthogneisses of uncertain affinity. The complex structure (Fig. 2.4) is well displayed in the 400 $\mathrm{m}$ cliffs in the north-east. The cliff section reveals a 
major early isocline deformed by later isoclines. The isoclines are deformed by an upright synform which is presumed to correlate with the upright-inclined folds in Rechnitzer Land and the north-western part of 'Janet Watson Halvø'. The cliffs are inaccessible, but detailed mapping in the gentle slopes to the south-east showed that major décollements are represented by belts of mylonite and ultramylonite. Some of the mylonites are folded by a large isocline which appears to be part of the second phase of the isoclinal folding seen in the cliff section. This relationship suggests that belts of mylonite formed in association with nappes before the period of younger upright-inclined folding. The major tectonic slide separating the south-eastern part of 'Janet Watson Halvø' from the north-western part (Figs 1, 2.4) has been inferred from the difference in structural complexity and the distribution of the pink hornblendic orthogneisses.

\section{Lindhard $\emptyset$}

The Bagfjord Fault which separates Rechnitzer Land and 'Janet Watson Halvø' from the central block forming most of Lindhard $\emptyset$ is exposed in the extreme southwest of the island (Fig. 1), although much is concealed by glacial deposits. The fault zone is steep, it is marked by reddened, epidotised and brecciated gneisses up to $c$. $50 \mathrm{~m}$ wide with veins of quartz or carbonate and it is presumed to have a dextral displacement on the grounds of the distribution of pink hornblendic orthogneisses and marble on each side of the fracture.

The north-west and central parts of Lindhard $\varnothing$ can be subdivided into three tectonic units that are separated by relatively narrow belts of SE-dipping mylonites which we regard as tectonic slides (Fig. 1). The north-western unit contains abundant supracrustal rocks, especially marble, sheets of pink porphyritic orthogneiss and a wide belt of mylonitised orthogneisses in the extreme north-west. The central unit, in contrast, is characterised by sheets of pink porphyritic orthogneiss, grey homogeneous orthogneiss and undifferentiated grey orthogneisses with subordinate supracrustal rocks. Old orthogneisses with local enclaves of gabbroanorthosite are common in parts of the north-western and south-eastern units. The latter contains sheets of pink schlieric orthogneisses similar to the younger facies of the mixed orthogneisses.

The structure of the north-western unit comprises a series of asymmetric antiforms and synforms plunging gently south-west coaxial with the regional linear fabric (Figs 1b, 2.3). A wide belt of gently dipping, mylonitised orthogneisses intersheeted with marble mélanges occurs in the extreme north-west (Fig. 1). The belt drops down to the north-west on a series of asymmetric folds which are also coaxial with the linear fabric and shallow NE-directed displacement indicated by feldspar $\sigma$-structures (Chadwick et al., 1990). These north-westerly verging folds are believed to correlate with the upright-inclined folds in the north-western part of Rechnitzer Land and 'Janet Watson Halvø' (Fig. 1b).

The asymmetric folds may be associated with a large synform marked by the sheets of pink porphyritic gneisses in the north-west of the north-western tectonic unit. This synform extends from Kap Jarner south-west across the head of Kavalerfjord (Fig. 1b). A sheet of pink orthogneiss also outlines a major synform extending south-westwards across Kavalerfjord. Its continuation further south-west may be antiformal, a relation suggesting the presence of a major sheath structure cored by mixed gneisses and old orthogneisses with locally abundant enclaves of gabbro-anorthosite. This structure deforms mylonites and earlier isoclines with strongly attenuated limbs.

The central tectonic unit comprises a regional synform with a gently plunging, gently curved hinge line. The gently dipping lower limb appears to be strongly attenuated in contrast with the overturned upper limb which dips steeply south-east. The central unit appears to have been juxtaposed against the north-western unit by a combination of overthrusting from the south-east and low-angle, NE-directed displacements on a major slide. This juxtaposition may have taken place prior to, or during, the generation of the regional synform.

Parasitic folds suggest that the south-eastern tectonic unit is also a major synform, but with no antiform intervening between the synform and that forming the central unit. This lack of an antiform is comparable with the relationship between the central unit and the complex structure of the north-western tectonic unit.

\section{Daniel Bruun Land}

The distribution of the principal types of orthogneiss suggests that there are two distinct tectonic units in the area mapped in the south-east of Daniel Bruun Land. The units are separated by a persistent sheet of pink hornblendic orthogneiss that occurs in the steeply dipping, overturned south-eastern limb of a regional synform (Fig. 2.2). This sheet also appears further northwest on the shallow limb of this large asymmetric structure. The sheet is overlain by mixed gneisses and sheets of pink augen gneiss. A tectonic slide marked by thin impersistent mylonites and marble 1-2 $\mathrm{m}$ thick on the east side of the sheet of pink hornblendic orthogneiss in the steep eastern limb of the synform forms the boundary between the tectonic units (Fig. 2.2). The south- 
easterly unit contains a range of supracrustal rocks and mixed gneisses intersheeted with pink augen gneiss, mixed orthogneisses and old orthogneisses. The stratiform gabbro-anorthosite complex of Kap Stop and other gabbroic rocks occur within this unit.

Little is known of the internal structure of the regional synform that is occupied by the north-westerly unit. Outcrops of marble and pink augen gneiss in the south-west show that earlier isoclines are deformed by the synform. The synform appears to close north-east of the area mapped, a relationship suggesting that the synform is boat-shaped with its hinge line plunging gently north-east in the south and gently south-west in the north. Its gross geometry suggests that it may correlate with the north-westerly verging upright-inclined folds of Lindhard $\varnothing$ and Rechnitzer Land (Fig. 1b).

The structure of the south-eastern unit is controlled by at least three sets of large-scale folds (Figs 1b, 2.1). The earliest recognisable phase is marked by the large outcrop of supracrustal rocks with intersheeted orthogneisses in the north-east. The earliest fold closure in this area thins dramatically into a few metres of paragneiss and local amphibolite which can be traced through younger large-scale folds to the south-west. The earliest closure and its intensely attenuated core are represented in the the north-west of section 1 in Fig. 2. The few metres of paragneiss forming the core extend at least $12 \mathrm{~km}$ along strike. This earliest core and its adjacent sheets of pink augen gneiss are folded by a second major isoclinal structure that is in turn folded over regional upright folds plunging gently north-east (Fig. 2.1). A complex pattern of regional folds is exposed on the slopes above Strømsund. Early isoclines are folded by younger large folds with axial surfaces dipping southeast. Curved fold hinge lines give rise to characteristic boat-shaped outcrops within intersheeted orthogneisses and marble. The two generations of nappe-scale isoclines are presumed to correlate with those in Lindhard $\varnothing$, 'Janet Watson Halvø' and Rechnitzer Land, whilst the upright-inclined structures that refold them are correlated with similar structures in these areas and the major synform that accommodates the north-westerly tectonic unit in the south-eastern part of Daniel Bruun Land (Fig. 1b). The Borgfjord Fault, a sinistral northwest-trending fracture concealed beneath the fjord itself, has been inferred from the relative distribution of the structures and principal types of orthogneisses in Lindhard $\varnothing$, Daniel Bruun Land and adjacent islands.

\section{Tectonic chronology and its implications}

Fold interference patterns, the distribution of asymmetric folds and regional relationships between the principal varieties of orthogneisses suggest that the regional structure is the result of two nappe-forming events and a younger period of upright-inclined folding with north-westerly vergence. These folding events occurred after the emplacement of extensive sheets of granites that are now represented by foliated and variably migmatised pink orthogneisses. A series of gneissforming events and injections of mafic sheets, now amphibolites, preceded emplacement of the pink granitic sheets, but these earlier events are not known in detail.

The nappe-forming events were associated with mylonitisation concentrated in relatively thin, gently dipping zones broadly concordant with foliation in the gneisses. The thickest zone of mylonites occurs in the west of Lindhard $\varnothing$ where mylonitised orthogneisses are intercalated with sheets of marble mélanges. The linear fabric and shear criteria in most of the mylonites indicate shallow, NE-directed displacement. Highgrade amphibolite facies conditions during nappe formation, mylonitisation and the younger period of upright-inclined folding are indicated by sillimanite parallel to the displacement direction in Lindhard $\varnothing$ and by diffuse pegmatites presumed to be partial melts coplanar with the younger folds in the north-west of Rechnitzer Land and in Daniel Bruun Land.

The linear fabric and the shallow displacement direction recorded in the mylonites are compatible with the sinistral displacement indicated by shear criteria in the Caledonian Storstrømmen shear zone reported by Friderichsen et al. (1990) and Strachan et al. (1991) west of Daniel Bruun Land. On the grounds of this relationship we conclude that the structures that formed after the emplacement of the sheets of pink granitic rocks in the south-west of Dove Bugt are Caledonian.

Small-scale, ductile extensional structures including listric faults, shear zones and conjugate shear bands in the gneisses and mylonites formed after the regional folding. These structures indicate $\mathbf{N}$ - and S-directed extensions which suggest that post-tectonic collapse of the Caledonian belt occurred longitudinally in the southwest of Dove Bugt. This longitudinal collapse is compatible with the extensional geometry of the Bessel Fjord shear zone to the south (Henriksen et al., 1989) and the Middle Devonian basin in East Greenland described by Larsen \& Bengaard (1991).

\section{References}

Chadwick, B., Friend, C. R. L. \& Higgins, A. K. 1990: The crystalline rocks of western and southern Dove Bugt, NorthEast Greenland. Rapp. Grønlands geol. Unders. 148, 127132. 
Friderichsen, J. D., Holdsworth, R. E., Jepsen, H. F. \& Strachan, R. A. 1990: Caledonian and pre-Caledonian geology of Dronning Louise Land, North-East Greenland. Rapp. Grønlands geol. Unders. 148, 133-141.

Henriksen, N. 1989: Regional geological investigations and 1:500 000 mapping in North-East Greenland. Rapp. Grønlands geol. Unders. 145, 88-90.

Henriksen, N., Friderichsen, J. D., Strachan, R. A.., Soper, N. J. \& Higgins, A. K. 1989: Caledonian and pre-Caledonian geology of the region between Grandjean Fjord and Bessel Fjord $\left(75^{\circ}-76^{\circ} \mathrm{N}\right)$, North-East Greenland. Rapp. Grønlands geol. Unders. 145, 90-97.
Larsen, P-H. \& Bengaard, H-J. 1991: Devonian basin initiation in East Greenland: a result of sinistral wrench faulting and Caledonian extensional collapse. J. geol. Soc. Lond. 148, 355-368.

Steiger, R. H., Harnik-Soptrajanova, G., Zimmerman, E. \& Henriksen, N. 1976: Isotopic age and metamorphic history of the banded gneiss at Danmarkshavn, East Greenland. Contrib. mineral. Petrol. 57, 1-24.

Strachan, R. A., Jepsen, H. F. \& Kalsbeek, F. 1991: Regional Caledonian structure of Hertugen af Orléans Land, NorthEast Greenland. Rapp. Gronlands geol. Unders. 152 (this volume). 